\title{
Survival rate and mortality of juvenile and immature eastern imperial eagles (Aquila heliaca) from Bulgaria studied by satellite telemetry
}

\author{
Prežívanie a mortalita mladých a imaturných orlov král’ovských (Aquila heliaca) \\ v Bulharsku na základe štúdia satelitnou telemetriou
}

\author{
Stoycho STOYCHEV, Dimitar DEMERDZHIEV, Svetoslav SPASOV, Bernd-Ulrich MEYBURG \\ \& Dobromir DOBREV
}

\begin{abstract}
A long-living species like $A$. heliaca has a natal dispersal period lasting several years. This period is crucial for the survival and conservation of the eagles. In this study we present mortality factors and the survival rate of juvenile and immature A. heliaca from Bulgaria as established by satellite telemetry. A total of 20 juvenile $A$. heliaca were fitted with GPS / Argos transmitters in their nests in Bulgaria. Fourteen birds were tracked till their death and the bodies were found. Tracking allows the survival rate of juvenile and immature $A$. heliaca to be estimated for the first time. It is $59.1 \%$ for the first calendar year, $83.3 \%$ for the second calendar year and $80.0 \%$ for the third calendar year. The main mortality factor for juvenile and immature $A$. heliaca from the Bulgarian population is electrocution, which caused $59.0 \%$ of the mortality cases. Other threats identified are shooting, poisoning and collisions. Most of the fatalities of these tracked eagles occurred in Bulgaria (50\%) and Turkey (43\%). Thus, Turkey is a key country for conservation of the Bulgarian population of $A$. heliaca during its dispersal period. Eagles from Bulgaria have been recorded dispersing further south, to Sudan and Saudi Arabia. Conservation efforts are needed both inside and outside Bulgaria in order to reduce mortality. International collaboration and the exchange of experiences should be part of any conservation strategy or plans focused on the eastern imperial eagle.
\end{abstract}

\begin{abstract}
Abstrakt: U dlhožijúceho druhu $A$. heliaca trvá disperzia z miesta vyliahnutia niekol'ko rokov. Je to obdobie vel'mi dôležité pre prežitie a ochranu orlov. $\mathrm{V}$ tejto štúdii prezentujeme faktory mortality a prežívanie mladých a imaturných $A$. heliaca $\mathrm{z}$ Bulharska na základe štúdia satelitnou telemetriou. Celkom bolo v hniezdach v Bulharsku vysielačkami GPS / Argos označených 20 mladých $A$. heliaca. Štrnást' vtákov bolo sledovaných až do smrti vrátane nálezov kadáverov. Ide o prvé takéto štúdium preživania mladých a imaturných jedincov $A$. heliaca. Prežívanie má hodnotu $59.1 \%$ v prvom kalendárnom roku, $83.3 \% \mathrm{v}$ druhom a $80,0 \%$ v tret'om kalendárnom roku. Hlavným faktorom mortality sledovaných jedincov z bulharskej populácie je smrt' v dôsledku zásahu elektrickým prúdom, ktorý spôsobil 59,0 \% prípadov mortality. Ďalšie identifikované hrozby sú zástrely, otravy a kolízie. Väčšina prípadov mortality sledovaných orlov nastala v Bulharsku (50\%) a v Turecku (43\%). Preto je Turecko klúčovou krajinou pre ochranu bulharskej populácie $A$. heliaca počas jeho disperzie. Orly z Bulharska sa rozptylujú aj d’alej na juh, do Sudánu a do Saudskej Arábie. Preto je potrebné ochranárske úsilie s ciel'om zníženia mortality tak vo vnútri ako aj mimo Bulharska. Medzinárodná spolupráca a výmena skúseností by preto mala byt' súčast'ou každej stratégie ochrany a plánov zameraných na ochranu orla král'ovského.
\end{abstract}

Key words: dispersal, tracking, birds of prey, electrocution, poisoning, shooting, Turkey, conservation strategy.

\footnotetext{
Stoycho Stoychev, Bulgarian Society for the Protection of Birds/BirdLife Bulgaria, P. O. Box 130, 6300 Haskovo, Bulgaria. Email: stoycho.stoychev@bspb.org.

Dimitar Demerdzhiev, Svetoslav Spasov, Dobromir Dobrev, Bulgarian Society for the Protection of Birds/BirdLife Bulgaria, 5Leonardo da Vinchi str., 4000 Plovdiv, Bulgaria. E-mail: dimitar.demerdzhiev@bspb.org, svetoslav.spasov@bspb.org, dobromir.dobrev@bspb.org.

Bernd-Ulrich Meyburg, Wangenheimstr 32, 14193 Berlin, Germany. E-mail: BUMeyburg@aol.com.

Acknowledgments: We would like to thank to Dimitris Vasilakis (WWF Greece), Guy Anderson (RSPB/BirdLife in UK) and Richard Cuthbert (RSPB/BirdLife in UK) for fitting several eagles with transmitters and training the BSPB team. We are obliged to Nikolai Terziev (BSPB/BirdLife Bulgaria) for climbing many trees with eagle nests. Our thanks also go to Tzeno Petrov, Georgi Popgeorgiev, Ivaylo Angelov, Girgina Daskalova, Georgi Gerdzhikov, Vanio Angelov, Dimitar Gradinarov and Maria Kiriakova from BSPB/BirdLife Bulgaria; Márton Horváth, András Kovács, Matyas Prommer, Tamás Szitta and Gabor Papp from MME/BirdLife Hungary; Petar Shurulinkov (National Natural History Museum - Sofia) Steffen Oppel (RSPB/BirdLife in UK) and Ciprian Fantana (ROS/BirdLife Romania), for providing valuable information and support. We are also grateful to Gradimir
} 
Gradev, Ivaylo Klisurov, Simeon Marin and all the colleagues from Green Balkans for sharing information and collaboration in the conservation work. Financial support was provided by the LIFE+ Program of the European Union within the project "Conservation of the Imperial Eagle and the Saker Falcon in key Natura 2000 sites in Bulgaria" or "Save the Raptors" (LIFE 07 NAT/BG/000068) and the project "Strandzha-Sakar - the realm of the eagles" (BG 2005/017-453.01.02.01-02) in the scope of a Bulgaria-Turkey Cross border cooperation program.

\section{Introduction}

The eastern imperial eagle (Aquila heliaca) is a Palaearctic species (Voous 1960), nesting from Central Europe, the Balkans, Central Asia, and South Siberia to China and Mongolia (BirdLife 2013). It is a priority for conservation efforts, since it is classified as a globally threatened species (IUCN 2013). The eastern imperial eagles breeding in Bulgaria are part of the Thracian meta-population of the species, estimated in total at 60-75 pairs (Demerdzhiev et al. 2011a). Since 2000, following a drastic population decline during the second half of the 20thcentury, the population of $A$. heliaca in Bulgaria has been increasing. The national population was estimated at 20-25 pairs in 2002 (Stoychev et al. 2004) and 25-30 pairs in 2008 (Demerdzhiev et al. 2011b).

There is little precise data on survival and the causes of mortality outside the natal areas of $A$. heliaca. Existing publications are based on ringing or a few individuals tracked by Argos transmitters (Meyburg et al. 1995, Danko 1996, Bagyura et al. 2002). Data from the Balkan population are even scarcer. Two ring recoveries and information from radio tracking within the country are known (Demerdzhiev 2011, Gradev et al. 2011). One bird from Bulgaria with a colour ring and a radio transmitter has been reported in Israel (Gradev et al. 2011). Recent studies suggest that not only the survival of adults but also conservation of juvenile and immature $A$. heliaca is important for increasing the population and maintaining its viability (Katzneret al. 2006).

In this paper we focus on the following issues, (1) what are the mortality causes for juvenile and immature A. heliaca from Bulgaria? (2) what is the survival rate of different age classes? (3) where does mortality occur? This information is a key to prioritizing the threats and the conservation efforts needed.

\section{Material and methods}

S t u d y a r e a s

The eastern imperial eagle population that was studied mainly inhabits the south-eastern part of Bulgaria, including the Tundzha river valley, the Sakar Mts., the Dervent Heights and the western Strandzha. One eagle originating from the Sredna Gora Mts. was also tracked.
Sakar is a low-mountain area with rounded hilltops and the relatively open river valleys of the Maritsa and Tundzha tributaries, located near the Bulgarian-Turkish border. The terrain elevation ranges between 50 and $856 \mathrm{~m}$ above sea level. The lower parts of the Sakar territory are made up of farmland, which has replaced forests of Quercus pubescens Willd. and Quercus virgiliana Ten. About $15 \%$ of the area is covered with dispersed xerothermal grass associations, dominated by Dichantium ischaemum L., Poa bulbosa L., etc., and more rarely, meso-xerothermal vegetation (Bondev 1991). The shrubs of Paliurus spina-christi L., mixed with Jasminum fruticans L. and in combination with the xerothermal grass formations, provide suitable habitats for various bird species. Many of the riverbeds and valleys in Sakar are still fringed by old trees of Populus alba L., hybrid poplars, Salix sp. etc., which provide nesting habitat for birds of prey. The neighbouring Dervent Heights is a low-mountain hilly area with a mosaic of different habitats, located to the east of the Tundzha River. The state border between Bulgaria and Turkey passes along main ridge of these hills. Their elevation is between 120 and $550 \mathrm{~m}$. About $20 \%$ of the territory of the Dervent Heights is covered by mixed deciduous forests of oak, most often Quercus cerris L., Q. frainetto Ten. and $Q$. pubescens Willd., in places mixed with Carpinus orientalis L. and Mediterranean elements. The western Strandzha is located in south-eastern Bulgaria. It covers the western part of the Strandzha Mts. and includes several types of habitats, the largest area being occupied by farmland, pastures and shrubs. The broadleaved forests are represented by Quercus cerris L. and $Q$. frainetto forests with Mediterranean elements. The woodlands alternate with open arable lands, pastures, grass formations, vineyards and orchards. The Tundzha river valley includes the middle and the lower reaches of the Tundzha River in the Sliven field and the adjacent Svetiiliyski Hills, Manastirski Hills and Bakadzhitsite Hills. The natural vegetation consists of forests, mainly formed by Quercus cerris L. and $Q$. frainetto. These ecosystems have remained as patches within arable land (Galabov 1982). The vegetation in the Sredna Gora Mts. consists mainly of forests of Fagus sylvatica L., Quercus petraea Matt. and Carpinus betulus L. (Galabov 


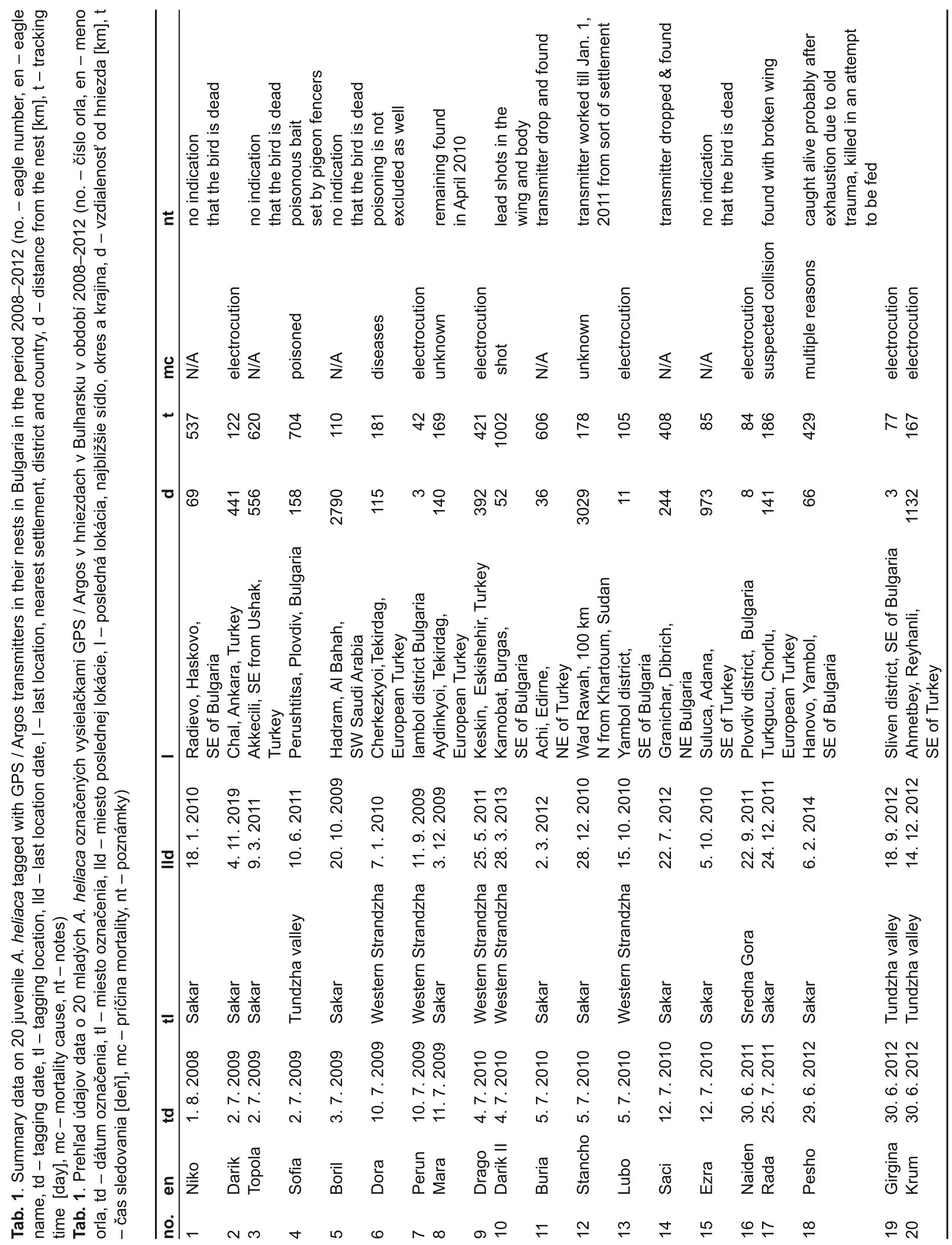




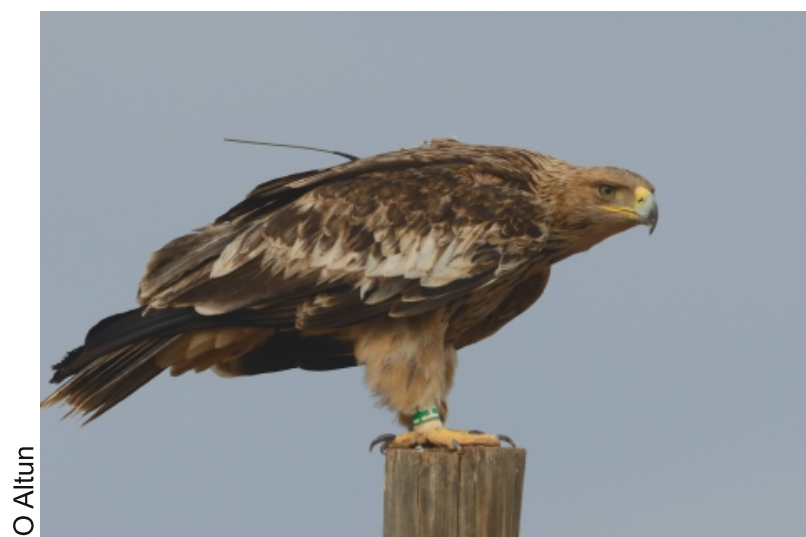

Fig. 1. A. heliaca called "Saci" satellite tagged on July 12, 2010 in the Sakar Mts, Bulgaria, has been photographed in good condition on December 11, 2011 in the area of Baypazari, central Turkey. In July 2012 the transmitter dropped successfully in the NE of Bulgaria.

Obr. 1. A. heliaca, nazvaný "Saci", označený satelitnou vysielačkou 12. júla 2010 v pohorí Sakar, Bulharsko, bol neskôr v dobrej kondícii fotografovaný 11. decembra 2011 v oblasti Baypazari, centrálne Turecko. V júli 2012 vysielačka úspešne odpadla v SV Bulharsku.

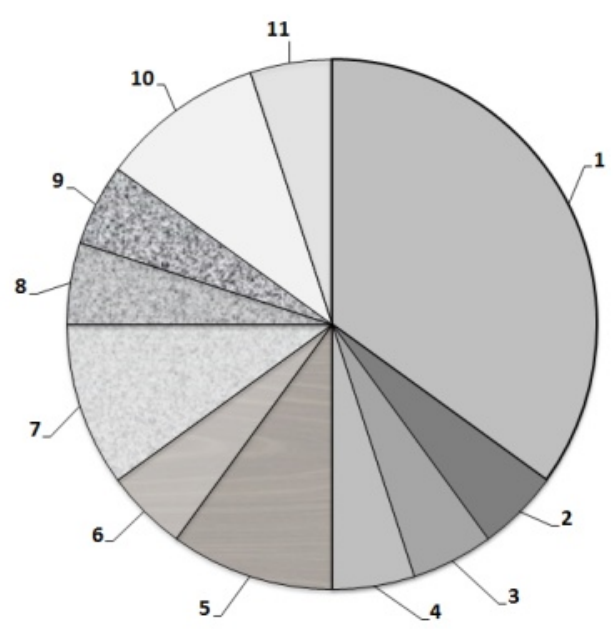

Fig. 2. Results from satellite tracking of juvenile and immature A. heliaca from Bulgaria tagged in the period 2008-2012 $(n=20 ; 1$ - electrocuted, 2 - shot, 3 - poisoned, 4 - injured, possible collision, 5 - dead, unknown reason, 6 - dead, probably diseases, 7 - transmitter stops, 1st year, 8 - transmiter stops, 3rd year, 9 - transmitter stops, 4th year, 10 - transmitter fell, 3rd year, 11 - multiple reasons).

Obr. 2. Výsledky satelitnej telemetrie mladých a imaturných A. heliaca označených v Bulharsku v období 2008-2012 ( $n=20$; 1 - usmrtený elektrickým prúdom, 2 - zastrelený, 3 - otrávený, 4 - poranený, pravdepodobne zrážka, 5 - mítvy, neznáma príčina, 6 - mítvy, pravdepodobne choroba, 7 - koniec aktivity vysielačky, 1. rok, 8 - koniec aktivity vysielačky, 3. rok, 9 - koniec aktivity vysielačky, 4. rok, 10 - spadnutá vysielačka, 3. rok, 11 - viac príčin).
1982). Artificial plantations of Pinus nigra Arnold and P. sylvestris L. cover significant areas.

\section{Satellite transmitters and}

$\mathrm{d}$ a $\mathrm{ta}$ colle ction

Between 2008 and 2012, we tagged 20 A. heliaca nestlings with satellite transmitters. The transmitters are produced by Microwave Telemetry Inc. (www.microwavetelemetry.com). Their weight is $70 \mathrm{~g}$. The transmitters were fixed to the birds' back using a Teflon harness (Fig. 1). In 2009 a metal harness with a plastic coat was used on three birds. The full transmitting equipment did not exceed $3 \%$ of the juveniles' body mass, as recommended by Kenward (2001), to minimize the effects of additional mass on the birds' movements. The device records the geographic coordinates of the location of the bird through a GPS system activated once at every two hours from 4:00 a. m. to 10:00 p. m. Messages from the microwave transmitter are collected through the Argos Processing Centre every two days from their web site. Only GPS locations were used in the analyses. Data decoding the messages received from Argos is done by GPS Data Parser software. In the case of mortality-mode activation or several close locations for a whole day, the field teams searched for the corpse in the areas of the last location. Summary information on date and place of tagging and distances to the last location is presented in Tab. 1 .

S u r vival rate e s t i m a t i o n

When calculating the survival rate we used, in addition to the satellite-tracked birds, data from four more $A$. heliaca from the study area. Three of them were fitted with VHF radio transmitters in their nests in 2007 and 2008 and tracked in Bulgaria over the next four years (Gradev et al. 2011, 2014), and one was initially fitted with a GSM transmitter in its nest in 2012 in Bulgaria (Gradev et al. 2014) and was later caught in Hungary and fitted with a GPS Argos (M. Horváth, pers. comm.).

We were able to estimate the survival rate of $A$. heliaca in three age classes: the first calendar year (eagles that survived until at least 31 December of the year of hatching), the second calendar year (eagles that survived up to 31 December of the next year), and the third calendar year (eagles that survived until at least 31 December of the third year). We calculated the percentage of individuals that are still alive (transmitters working) out of the whole number of birds with transmitters of this age class, including those that were found 
dead in that year. Birds whose transmitters stopped transmitting but whose bodies have not been found (so no proof that they are dead) were not included in the analyses of survival of the year when the transmitter stopped functioning. For example, if a transmitter stops working during the third calendar year (before 31 December) and the body is not found, this bird is not used for calculating the survival rate for the third calendar year age class. Such a bird is considered to be alive up to 31 December of the previous (second) year in order to calculate the total number of birds (dead and alive) for the second calendar year age class. This is why the sample size decreases with the age increase. For example, we have five eagles whose transmitters transmitted till the whole third calendar year of the eagles. Out of them, one was found dead and 4 survived up to 31 December of the third year - thus, $80.0 \%$ survival for the third calendar year. We do not calculate the survival rate for the fourth calendar year due to the small sample size - only two transmitters were working during the whole fourth calendar year of the birds and one more bird was found dead.

\section{Results}

We were able to track 14 out of 20 eagles till their death. In two other cases we found the transmitters only during the third calendar year of the eagles, so we assume that the stitches had decayed and the transmitter had dropped off. One of those birds had been previously seen in Romania with part of the harness hanging off, indicating that it was already falling apart (C. Fantana, pers. comm.). Later the transmitter was found about $15 \mathrm{~km}$ from the place where the bird was seen. There are four more birds whose last signal was a single location and the transmitters were not found. Two of those cases happened in the first calendar year of the eagles, one in the third and one in the fourth calendar year. For those cases we assume the following possible scenarios:

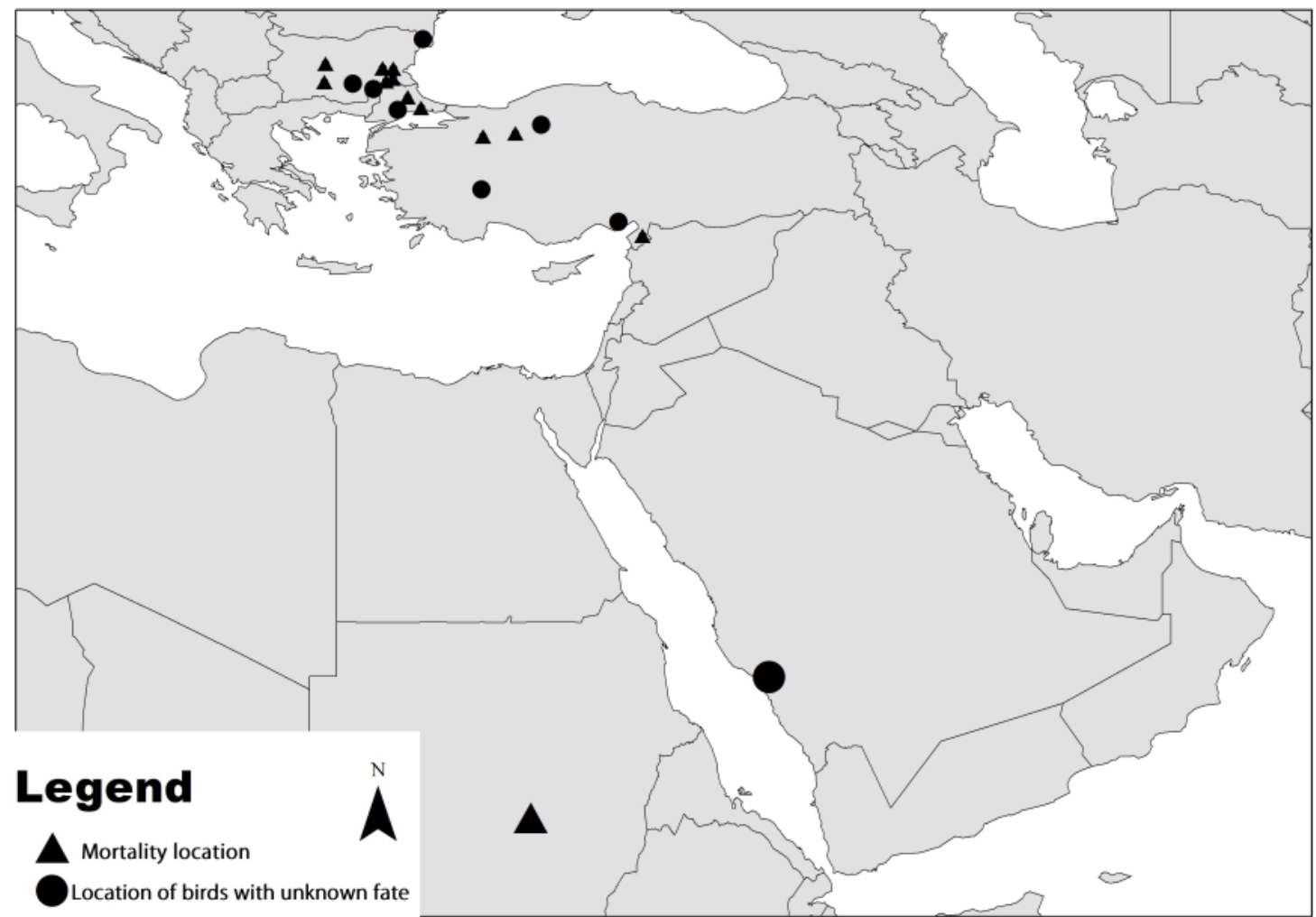

Fig. 3. Dispersal and mortality sites of juvenile and immature $A$. heliaca from Bulgaria tagged in the period 2008-2012. Triangles indicate the 14 mortality locations; dots indicate the six last single locations of birds with unknown fates $(n=20)$.

Obr. 3. Disperzia a miesta mortality mladých a imaturných A. heliaca z Bulharska označených v období 2008-2012. Trojuholníky označujú 14 lokalít mortality; krúžky označujú šest' posledných záznamov vtákov s neznámym osudom (n=20). 
1. The transmitter stopped working while still on a living bird;

2. The eagle moves further from the last location and died in circumstances that do not allow transmitting;

3. The transmitter dropped off of the bird, but it cannot transfer data due to a face-down position.

The third scenario is more likely for the two transmitters that stopped in the third and fourth calendar year. The fate of all birds tracked by us is presented in Fig. 2.

\section{Discussion}

D i s persal a $\mathrm{nd}$ mortality

The use of satellite transmitters in studies for juvenile and immature dispersal and survival, especially in the large raptor species which are moving many kilometres from their natal area, is the best way to monitor and improve knowledge about this period of their life.

Studies about $A$. heliaca dispersal have been carried out in Central Europe mostly by using information from ring recoveries. Juveniles ringed in Slovakia and Hungary have been found in Serbia, Croatia, Greece, Bulgaria, Turkey and the Middle East (Danko 1996, Bagyura et al. 2002). Recent data suggests that juvenile and immature eagles from Slovakia and Hungary stay mostly in the Pannonian Basin. However, some individuals tracked via PTTs went to Greece, Turkey

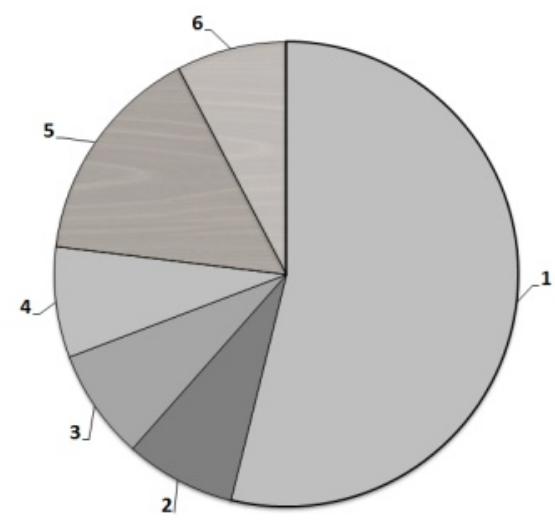

Fig. 4. Mortality cause of satellite-tracked juvenile and immature $A$. heliaca from Bulgaria tagged in the period 2009-2012 ( $n=12$; 1 - electrocution, 2 - shooting, 3 - poisoning, 4 - injury, possible collision, 5 - probably diseases, 6 - multiple reasons).

Obr. 4. Príčiny mortality mlád'at' a imaturných $A$. heliaca sledovaných satelitnou telemtriou v Bulharsku v období 2009-2012 ( $n=12 ; 1$ - usmrtený elektrickým prúdom, 2 - zastrelený, 3 - otrávený, 4 - poranený, pravdepodobne zrážka, 5 - pravdepodobne choroba, 6 - viac príčin). through the Balkans and even to Africa (A. Kovac, M. Horváth, L. Deutschová, unpubl. data). One ringed juvenile from Slovakia was photographed in Greece and one ring belonging to an eastern imperial eagle from Slovakia was found in Spain (M. Dravecký, pers. comm.). There is not much data on the dispersal of the juvenile and immature $A$. heliaca from the Balkan population. One rehabilitated juvenile from Bulgaria released in the first calendar year of its life was found dead in the fourth calendar year $70 \mathrm{~km}$ from the nest site (Demerdzhiev 2011). Two individuals studied by radio telemetry were recorded in Bulgaria and the border area of Turkey during the first two years of life. However, due to the technical limitation of the method, it is not known whether they flew further away from the natal area and what their final fate was. One bird with a radio transmitter and a colour ring was seen in Israel (Gradev et al. 2011). Quantitative data about the places of dispersal and related mortality of juvenile and immature $A$. heliaca from Bulgaria and the Balkans are absent.

We recorded mortality cases in Bulgaria, Turkey and Sudan. In one additional case the last single location is in Saudi Arabia. Fig. 3 presents the locations where dead eagles have been found and the location where the last GPS coordinates were received for those eagles whose fate remains unknown. There are 9 such locations in Turkey, 9 in Bulgaria, one in Sudan and one in Saudi Arabia.

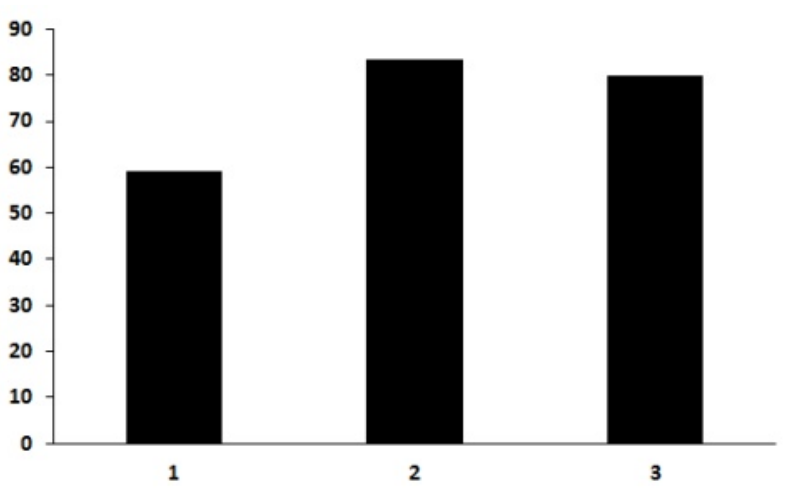

Fig. 5. Survival rate of juvenile and immature $A$. heliaca from Bulgaria established by satellite and radio tracking in the period 2007-2013 $(n=22 ; x$ axis - eagle age, 1 - 1st calendar year, 2 - 2nd calendar year, 3 - 3rd calendar year; y axis - survival rate $[\%])$.

Obr. 5. Podiel prežívania mladých a imaturných $A$. heliaca z Bulharska na základe satelitnej a rádiovej telemtrie $v$ období 2007-2013 ( $n=22$; os $x$ - vek orla, 1 - 1. kalendárny rok, 2 - 2. kalendárny rok, $3-3$. kalendárny rok; os y-podiel prežívania [\%]). 
The bulk of registered mortality cases happen in Bulgaria and Turkey (Fig. 3). Thus, conservation efforts in Turkey would contribute significantly to the conservation of the Bulgarian population of $A$. heliaca. Eastern imperial eagles from Hungary and Slovakia disperse to Turkey as well (Danko 1996, Bagyura et al. 2002, M. Horváth, L. Deutschová, pers. comm.). Conservation efforts in Turkey would therefore contribute to the conservation of the A. heliaca population in Central Europe as well.

\section{Mort a lity c a u se s}

Data on threats to the Bulgarian population of $A$. heliaca is found in various sources (Petrov \& Stoychev 2002, Demerdzhiev 2011, Stoychev et al. 2013). However, those are based on casual observations. There is no data on the threats and mortality during their dispersal outside of Bulgaria.

Fourteen eagles fitted with transmitters have been found dead. The mortality causes that were identified for 12 of them are presented on Fig. 4. Electrocution is the main threat, contributing to $59.0 \%$ of the casualties. In older publications about $A$. heliaca in Bulgaria this factor was underestimated or only referred to as a potential threat due to lack of data, since the Bulgarian population is small and the chance of finding electrocuted birds without tracking is limited (Petrov $\&$ Stoychev 2002, Demerdzhiev et al. 2011). Four of the recorded electrocuted eagles were found in Bulgaria and three in Turkey. The other threats established include shooting, poisoning, collision and disease. However, telemetry as a method may lead to underestimation of shooting since if a bird is shot to dead then the poachers may quickly get rid of the transmitter. In one similar case the people who caught an exhausted eagle (named Pesho) tried to deactivate the transmitter and were revealed after a police investigation in Bulgaria. The autopsy found out that the eagle had an old trauma that may have been the reason that a local fisherman was able to catch him. Finally, they tried to feed it and most probably caused gulping. In another case an eagle was found dead and the autopsy revealed heart disease. However, in the area where it was found in Turkey there were poisoning accidents at that time and several common buzzards were found dead (Jose Tavares, pers. comm.), thus poisoning is not excluded.

S u r viva 1 ra t e

The results from the survival rate estimate are presented in Fig 5. Survival is lowest during the first calendar year of the eagle's life $(59.1 \%, \mathrm{n}=22$ individuals $)$ and higher in second $(83.3 \%, \mathrm{n}=12$ individuals) and third year $(80.0 \%, \mathrm{n}=5$ individuals). The global observed survival rate from fledging to the start of the fourth calendar year, counted as number of birds that survive out of those with known fate (survivors and confirmed as dead) is $25.0 \%(\mathrm{n}=16)$. This is very similar to the survival rate of Aquila adalberti for the same life period (from fledging to the start of the fourth calendar year) $24.0 \%$, as established by Ortega et al. (2009).

\section{Con c l u s i o n s}

Satellite tracking allows the survival rate of juvenile and immature $A$. heliaca to be estimated for the first time. This is the basis for modelling and population viability analyses. The survival rate of $A$. heliaca from fledging to the start of the fourth calendar year is similar to the survival rate for the same life period for $A$. adalberti, the population of which is growing. Further modelling would provide information on the possible population development of the $A$. heliaca in Bulgaria.

The main mortality factor for juvenile and immature A. heliaca from the Bulgarian population is electrocution, which causes $59.0 \%$ of the casualties. Most of the fatalities happen in Turkey and Bulgaria. Turkey is a key country for the conservation of the Bulgarian population of $A$. heliaca during its dispersal. Eastern imperial eagles from Bulgaria have been recorded to disperse further South to Sudan and Saudi Arabia. Conservation efforts focused on electrocution are needed both inside and outside of Bulgaria in order to reduce mortality. International collaboration and exchange of experience should be part of the $A$. heliaca conservation strategy or plans.

\section{Refrences}

Bagyura J, Szitta T, Haraszthy L, Firmánszky G, Viszló L, Kovács A, Demeter I \& Horváth M2002: Population increase of eastern imperial eagle (Aquila heliaca) in Hungary between 1980 and 2000. Aquila 107-108: 133-144.

BirdLife International 2013: Species factsheet: Aquila heliaca. Retrieved December 1, 2013, from http://www.birdlife.org.

Danko S̆ 1996: Beringungsergebnisse am Kaiseradler Aquila heliaca im Nordwesten des Brutareals, 389-403. In: Meyburg B-U \& Chancellor Rd (eds), Eagle Studies. World Working Group on Birds of Prey (WWGBP), Berlin, London \& Paris, 549.

Demerdzhiev D 2011: Iztochniyat tsarski orel (Aquila heliaca heliaca Savigny, 1809) (Accipitridae 
- Aves) v Balgariya - razprostranenie, biologiya, ekologiya, chislenost i merki za opazvane [Eastern imperial eagle (Aquila heliaca heliaca Savigny, 1809) (Accipitridae - Aves) in Bulgaria - distribution, biology, ecology, numbers, and conservation measures]. Synopsis of the $\mathrm{PhD}$. thesis. BASNMNH, Sofia, 39. [In Bulgarian]

Demerdzhiev D, Horváth M, Kovács A, Stoychev S \& Karyakin I 2011a: Status and population trend of the eastern imperial eagle (Aquila heliaca) in Europe in the period 2000-2010. Acta zoologica Bulgarica Supplementum 3: 5-14.

Demerdzhiev D, Gradev G, Stoychev S, Ivanov I, Petrov T \& Marin S 2011b: Increase of the population of the eastern imperial eagle (Aquila heliaca) in Bulgaria. Acta zoologica Bulgarica Supplementum 3: 41-54.

Galabov Z 1982: Fiziogeografski rayoni [Physiographic regions], 115-215. In: Galabov Z (ed), Geografiya na Balgariya , tom 3. Fiziogeografiya [Geography of Bulgaria, vol. 3. Physiography]. BAS, Sofia, 315. [In Bulgarian]

Gradev G, Matarranz V, Dobreva E, Popov D, Marin S, Ivanov I \& Zhelev P 2011: First results of the tracking of eastern imperial eagles(Aquila heliaca) tagged with radio-transmitters in Bulgaria. Acta Zoologica Bulgarica Supplementum 3: 21-28.

Gradev G, Zhelev P, Marin S 2014: Identifying the home range of breeding pairs of eastern imperial eagles (Aquila heliaca) through radio-tracking in Bulgaria. Slovak Raptor Journa 8(1): 63.

IUCN 2013: IUCN Red list of threatened species. Version 2013.2. Retrieved December 1, 2013 from www.iucnredlist.org.

Katzner T, Bragin E \& Milner-Gulland E 2006: Modeling populations of long-lived birds of prey for conservation: a study of imperial eagles (Aquila heliaca) in Kazakhstan. Biological Conservation 132:
322-335. DOI: http://dx.doi.org/10.1016/j.biocon.2006.04.024.

Kenward R 2001: A manual for wildlife radio tagging. 2nd edition. Academic Press, New York, 350.

Ortega E, Manosa S, Margalida A, Sanchez R, Oria J \& Gonzalez L 2009: A demographic description of the recovery of the vulnerable Spanish imperial eagle Aquila adalberti. Oryx 43: 113-121. DOI: http://dx.doi.org/10.1017/S0030605307991048.

Meyburg B-U, Haraszthy L, Meyburg C \& Viszlo L 1995: Satelliten und Bodentelemetrie A. heliaca binemjungen Kaiseradler Aquila heliaca: Familien auflösung und Dispersion. Vogelwelt 116: 153-157.

Petrov T \& Stoychev S 2002: Natsionalen plan za deystvie za tsarskiya orel (A. heliaca) $\mathrm{v}$ Balgariya [National Action Plan for the imperial eagle ( $A$. heliaca)], 132-161. In: Iankov P (ed), Global threatened birds in Bulgaria. National Action plans for the conservation. Part 1. BSPB-MOSV, Conservation Series, Book 4, BSPB, Sofia, 227. [In Bulgarian]

Stoychev S, Ivanov I, Petrov T, Marin S, Demerdzhiev D, Gradev G \& Domuschiev D 2004: Status of the eastern imperial eagle (Aquila heliaca) in Bulgaria between 1994 and 2002, 653-660. In: Chancellor RD \& Meyburg B-U (eds): Raptors worldwide. Proceedings of the VI world conference on birds of prey and owls. Budapest, Hungary 18-23 May 2003World Working Group on Birds of Prey and Owls \& MME/BirdLife Hungary, Berlin \& Budapest, 867.

Stoychev S, Demerdzhiev D \& Petrov T 2013: Plan za deystvie za opazvane na krastatiya orel (A. heliaca) v Balgariya 2013-2022 [National Action plan for the conservation of the eastern imperial eagle $(A$. heliaca) in Bulgaria 2013-2022]. Ministry of Environment and Water, Sofia, 76. [In Bulgarian]

Voos KH 1960: Atlas of European birds. Nelson, Edinburgh, 284. 